\title{
HFE Gene Mutation Associated with the Severity of Gestational Diabetes Mellitus in Belarusian Women
}

\author{
Larysa Sivitskaya ${ }^{1}$, Nina Danilenko ${ }^{1}$, Zoya Zabarouskaya ${ }^{2}$, Oleg Davydenko ${ }^{1}$ \\ ${ }^{1}$ Institute of Genetics and Cytology, National Academy of Sciences, Minsk, Belarus \\ ${ }^{2}$ Belarusian State Medical University, Minsk, Belarus \\ Email: cytoplasmic@mail.ru
}

Received October 2, 2012; revised November 5, 2012; accepted December 8, 2012

\begin{abstract}
To determine whether the H63D and $\mathrm{C} 282 \mathrm{Y}$ mutations in HFE (hemochromatosis) gene are associated with the risk of gestational diabetes mellitus (GDM), we conducted the study of 65 incident cases. The class of gestational diabetes (A1, A2, B) in pregnant women was defined based on the results of glycemic profile and 75-g oral glucose tolerance test. Two single nucleotide polymorphisms (H63D and C282Y) in HFE gene were genotyped by PCR and RFLP (Restriction Fragment Length Polymorphism). The frequencies of mutations in patients cohort were: 0.14 for H63D and 0.02 for $\mathrm{C} 282 \mathrm{Y}$, which are similar to the data reported for Belarusian population ( 0.16 and 0.04 respectively). The detailed analysis of case subjects indicated association of H63D mutation with the severity of gestational diabetes mellitus. In the frequencies of H63D mutation and genotypes between the case subjects with A1 and B gestational diabetes were detected significant differences. Our data indicated that the presence of H63D mutation in pregnant women with GDM aggravates the disease —odds ratio 7.4 (95\% CI 1.8 - 30.5). Women with gestational diabetes have severe increased risk for illness progressing to class B if they are H63D mutation carriers.
\end{abstract}

Keywords: Gestational Diabetes Mellitus; HFE Gene; H63D and C282Y Mutations; Belarusian Population

\section{Introduction}

Gestational diabetes mellitus (GDM) is a form of glucose intolerance diagnosed during pregnancy. According to the American Diabetes Association, about 4\% of pregnant women suffer from GDM. It is 100 times more frequent than cases of pregnancy with type 1 or type 2 diabetes mellitus $[1,2]$. There are several risk factors for the development of GDM, the main are considered glycolsuria, ketonuria, obesity, diabetes mellitus in 1st degree relatives $[3,4]$. But these are not enough to confirm or exclude the chance of GDM manifestation, predict the severity of abnormal carbohydrate metabolism during the gestation or the risk of diabetes mellitus development after childbirth.

The role of genotype should be considered as one of the leading reasons of GDM. Number of human genes was investigated dealing with GDM: HLA, SUR1 (sufonylurea receptor gene), GCK (glucokinase gene), TCF7L2 (transcription factor 7-like 2 gene), HFE (hemochromatosis gene) and others with contradicting results [5-10].

Several articles about correlation between HFE gene mutations and abnormal carbohydrate metabolism were published in recent years [10-12]. The gene is located at 6 p21.3 and encodes a protein necessary for iron transport into cells. In 1996 Feder et al. described two missence mutations in HFE gene- $\mathrm{C} 282 \mathrm{Y}$ and H63D. They are associated with increased iron absorption and progressively deposition in the pancreas, heart, liver, joints and others tissues [13]. In the last decade, the attention was focused on the study of the iron role in the abnormal carbohydrate metabolism [14,15]. This is particularly important with regard to the GDM, because there is no physiological blood loss during pregnancy, so excess iron cannot be removed from the body in this period. Moreover, for the anemia prevention iron supplementation are recommended for pregnant women, as a result increases risk of iron overload in subjects with C282Y and H63D genotype.

The aim of this study was to evaluate the association between $\mathrm{C} 282 \mathrm{Y}$ and $\mathrm{H} 63 \mathrm{D}$ mutations and the risk of gestational diabetes mellitus in Belarusian pregnant women.

\section{Methods}

\subsection{Study Sample}

The case subjects reported in the study are pregnant women suffering from GDM. They were attending the Pregnancy Pathology Department of the 1st City Clinical Hospital (Minsk, Belarus) and National Research Center 
"Mother and Child" (Minsk, Belarus) between January 2007 and December 2009. Written informed consent about voluntary participation in the study was obtained from the all case subjects. The study has been considered and approved specifically by the Bioethics Committee of the Belarusian State Medical University (Minsk, Belarus) and the Scientific Board of the Institute of Genetics and Cytology of the National Academy of Sciences (Minsk, Belarus).

The case cohort consisted of 65 Belarusian pregnant women with GDM diagnosed according to the National Diabetes Data Criteria [16]. The class of gestational diabetes (A1, A2, B1 and B2) in pregnant women was defined based on the results of glycemic profile and 75-g oral glucose tolerance test between 24 and 32 weeks of gestation. Criteria of GDM classification are detailed in the Table 1.

The 736 healthy Belarusian inhabitants (age: $24.9 \pm$ 4.5) were recruited in large screening study conducted in the Institute of Genetics and Cytology of the National Academy of Sciences (Minsk, Belarus) between January 2005 and May 2006 [17].

The patients were screened for additional GDM risk factors. The description of the case subjects in details is presented in the Table 2. Glycosuria was diagnosed

Table 1. Classification of gestational diabetes mellitus adapted to Belarusian pregnant women.

\begin{tabular}{|c|c|c|}
\hline Class & $\begin{array}{l}\text { Laboratory characteristic of } \\
\text { glycemia }\end{array}$ & Treatment \\
\hline \multirow{3}{*}{ A1 } & Fasting (basal) $<5.3 \mathrm{mmol} / 1$ & Diet \\
\hline & $\begin{array}{l}\text { Postprandial ( } 2 \text { hours after } \\
\text { meals })<7.8 \mathrm{mmol} / 1\end{array}$ & Adequate physical activity \\
\hline & $\begin{array}{l}\text { Abnormality of } 2-3 \\
\text { parameters of the } 75-g \text { OGTT }\end{array}$ & \\
\hline \multirow{4}{*}{$\mathrm{A} 2$} & Fasting (basal) $5.3-6.1$ & Diet \\
\hline & $\begin{array}{l}\mathrm{mmol} / 1 \\
\text { Postprandial }(2 \text { hours after } \\
\text { meals }) 7.8-8.0 \mathrm{mmol} / 1\end{array}$ & $\begin{array}{l}\text { Insulin therapy (short-acting } \\
\text { insulin } \\
\text { before meals) if: }\end{array}$ \\
\hline & $\begin{array}{l}\text { Abnormality of } 2-3 \\
\text { parameters of the } 75-\mathrm{g} \text { OGTT }\end{array}$ & $\begin{array}{l}\text { 1) basal glycemia }>5.3 \\
\mathrm{mmol} / \mathrm{l}\end{array}$ \\
\hline & & $\begin{array}{l}\text { 2) postprandial glycemia }> \\
7.8 \mathrm{mmol} / \mathrm{l}\end{array}$ \\
\hline \multirow[b]{2}{*}{ B1 } & Fasting (basal) $>6.1 \mathrm{mmol} / 1$ & Diet \\
\hline & $\begin{array}{l}\text { Postprandial ( } 2 \text { hours after } \\
\text { meals })>8.0 \mathrm{mmol} / 1\end{array}$ & $\begin{array}{l}\text { Insulin therapy } \\
\text { (basis-bolus treatment- } 3 \\
\text { injections of short-acting } \\
\text { insulin and } 1 \text { injection of } \\
\text { prolonged action insulin) }\end{array}$ \\
\hline \multirow[b]{2}{*}{ B2 } & Fasting (basal) $>6.1 \mathrm{mmol} / 1$ & Diet \\
\hline & $\begin{array}{l}\text { Postprandial ( } 2 \text { hours after } \\
\text { meals })>11.1 \mathrm{mmol} / 1\end{array}$ & $\begin{array}{l}\text { Insulin therapy } \\
\text { (basis-bolus treatment-3 } \\
\text { injections of short-acting } \\
\text { insulin and } 2 \text { injection of } \\
\text { prolonged action insulin) }\end{array}$ \\
\hline
\end{tabular}

when urine glucose level was $>6.7 \mathrm{mmol} / \mathrm{l}$, ketonuria - urine ketone bodies level $\geq 5.0 \mathrm{mmol} / \mathrm{l}$.

Criteria of pregnancy-induced hypertension were: edema, proteinuria, vasospasms of the arteries (sustained blood pressure elevation of 140/90 or more).

\subsection{DNA Analysis}

For the case cohort study $50-100 \mathrm{mcl}$ (1 - 2 drops) of peripheral blood was collected between 33 and 38 weeks of pregnancy. DNA was isolated with proteinase $\mathrm{K}$ and phenol-chloroform purification [18].

Two single nucleotide polymorphisms (H63D and $\mathrm{C} 282 \mathrm{Y}$ ) in HFE gene were genotyped by PCR and RFLP (Restriction Fragment Length Polymorphism). The polymorphisms were amplified separately in $15 \mathrm{mcl}$ of a reaction mixture containing $5-10 \mathrm{ng}$ of genomic DNA, 2 mcl of $10 \times$ amplification buffer solution ("Fermentas", Lithuania), $1.5 \mathrm{mM} \mathrm{MgCl}, 200 \mathrm{mcM}$ of each deoxynucleotide triphosphate (dNTP), $2.5 \mathrm{U}$ of Taq DNA polymerase (Fermentas, Lithuania), and $0.3 \mathrm{mcM}$ of each primer. A MyCycler ${ }^{\mathrm{TM}}$ thermal cycler (BIORAD) was used for PCR. Conditions for successful genotyping H63D and C282Y are presented in Table 3, where primers, annealing temperature, endonucleases ("Fermentas", Lithuania) are indicated.

Table 2. Characteristic of the case subjects.

\begin{tabular}{lc}
\hline \multicolumn{1}{c}{ Characteristic } & $\begin{array}{c}\text { Case subjects, } \mathrm{n} \\
\text { (frequency) }\end{array}$ \\
\hline Total & 65 \\
Age (years) & $28.9 \pm 5.7^{*}$ \\
Age older than 30 & $31(0.48)$ \\
BMI (kg/m ${ }^{2}$ ) & $30.4 \pm 4.5^{*}$ \\
Overweight, obesity (BMI $\left.\geq 27 \mathrm{~kg} / \mathrm{m}^{2}\right)$ & $28(0.43)$ \\
Pronounced glycosuria & $12(0.18)$ \\
Ketonuria & $13(0.20)$ \\
$\begin{array}{l}\text { Diabetes mellitus in 1st degree relatives } \\
\text { Fetal macrosomia in the current or previous } \\
\text { pregnancy (birthweight } \geq 4000 \mathrm{~g})\end{array}$ & $18(0.28)$ \\
$\begin{array}{l}\text { Hydramnion in the current or previous } \\
\text { pregnancy }\end{array}$ & $7(0.11)$ \\
$\begin{array}{l}\text { Noncarrying of previous pregnancies } \\
\text { (miscarriages, non-developing or ectopic } \\
\text { pregnancies) }\end{array}$ & $6(0.09)$ \\
Pregnancy-induced hypertension & $11(0.17)$ \\
Class A1 GDM & $54(0.83)$ \\
Class A2 GDM & $40(0.61)$ \\
Class B1 GDM & $14(0.22)$ \\
Class B2 GDM & $9(0.14)$ \\
\hline
\end{tabular}

*Indicates mean \pm standard deviation. 
Table 3. Primers, PCR conditions and endonucleases for genotyping.

\begin{tabular}{|c|c|c|c|c|c|}
\hline Polymorphism & Primers & $\mathrm{T}_{\mathrm{a}}$ & PCR product, bp & Endonuclease & $\begin{array}{l}\text { Restriction fragments, bp } \\
\text { (allele type) }\end{array}$ \\
\hline $\begin{array}{c}\mathrm{C} 282 \mathrm{Y} \\
\text { (rs } 1800562)^{*}\end{array}$ & $\begin{array}{l}\text { 5'CTACCCCCAGAACATCACCA 3' } \\
\text { 5'CTCCAATGACTAGGGTGCCA 3' }\end{array}$ & $62^{\circ} \mathrm{C}$ & 394 & RsaI & $\begin{array}{l}\text { 126, } 268 \text { (allele N) } \\
29,126,239 \text { (allele C282Y) }\end{array}$ \\
\hline $\begin{array}{c}\mathrm{H} 63 \mathrm{D} \\
\text { (rs 1799945)* }\end{array}$ & $\begin{array}{l}\text { 5'CCCTCTCCACATACCCTTGCTG 3' } \\
\text { 5'AAGCTTTGGGCTACGTGGATGATCAG 3', }\end{array}$ & $60^{\circ} \mathrm{C}$ & 212 & MboI & $\begin{array}{l}41,72,99 \text { (allele N) } \\
72,140 \text { (allele N63D) }\end{array}$ \\
\hline
\end{tabular}

*Reference SNP ID number.

Visualization of restriction fragments was performed in $8 \%$ and $5 \%$ polyacrylamide gel for $\mathrm{H} 63 \mathrm{D}$ and $\mathrm{C} 282 \mathrm{Y}$ respectively.

\subsection{Statistical Analysis}

The $\chi^{2}$ test was used to compare the frequencies of alleles and genotypes. For small cohort comparing the Fisher's Exact Test (FET) was applied. Genotype frequencies were tested for Hardy-Weinberg equilibrium. An odds ratio (OR) and 95\% CI were calculated as described [19].

\section{Results and Discussion}

The allele frequencies were 0.14 for H63D and 0.02 for C282Y as presented in the Table 4. We did not find $\mathrm{C} 282 \mathrm{Y}$ homozygotes and compound heterozygotes in the case subjects. Observed genotype frequencies are consistent with Hardy-Weinberg equilibrium: $\chi^{2} 0.04$, P 0.85 for $\mathrm{C} 282 \mathrm{Y}$ and $\chi^{2} 0.07$, P 0.80 for H63D polymorphism. To determine whether these mutations could be a risk factor for the development of gestational diabetes mellitus, the prevalence of H63D and C282Y in case subjects was compared to that of the population rate (Table 4).

There were no significant differences in genotype and allele rates of $\mathrm{H} 63 \mathrm{D}\left(\chi^{2} 0.3, \mathrm{P} 0.58\right)$ and $\mathrm{C} 282 \mathrm{Y}$ (FET, P 0.62 ). The average frequencies of HFE mutations and genotypes in Belarusian population were in HardyWeinberg equilibrium $(\mathrm{P}>0.05)$ [17]. According to the odds ratio index, $\mathrm{C} 282 \mathrm{Y}$ (OR 0.6; 95\% CI 0.2 - 2.1; P 0.60 ) and H63D (OR 0.9; 95\% CI 0.5 - 1.6; P 0.77) are probably not associated with the GDM risk in Belarusian women.

To study whether the H63D and C282Y mutations in HFE gene are associated with the severity of GDM, we compared the different classes of the disease. The largest group was A1 class (40 persons), the next one-A2 class (14 persons). Pregnant women with B1 and B2 GDM were combined in one group B because of small sample size.

The prevalence of $\mathrm{C} 282 \mathrm{Y}$ did not differ from various GDM classes (FET, $P>0.05$ ). No significant differences in H63D between the case subjects with $\mathrm{A} 1$ and $\mathrm{A} 2$ gestational diabetes were detected as well (Table 5). But the frequency of H63D in patients with B class was statisticcally higher than in A1 class women (FET, P 0.003). We
Table 4. C282Y and H63D frequencies in case subjects and Belarusian population.

\begin{tabular}{lcc}
\hline & $\begin{array}{c}\text { Case subjects, } \\
\mathrm{n} \text { (frequency) }\end{array}$ & $\begin{array}{l}\text { Population, } \\
\mathrm{n} \text { (frequency) }\end{array}$ \\
\hline C282Y & & \\
Total & 65 & 736 \\
Genotype C282Y/C282Y & $0(0.00)$ & $2(0.003)$ \\
Genotype C282Y/N & $3(0.05)$ & $51(0.07)$ \\
Genotype N/N & $62(0.95)$ & $683(0.93)$ \\
OR & $0.6 ; 95 \% \mathrm{CI} 0.2-2.1$ \\
Allele C282Y & $3(0.02)$ & $55(0.04)$ \\
Allele N & $127(0.98)$ & $1417(0.96)$ \\
H63D & & \\
Total & 65 & 771 \\
Genotype H63D/H63D & $1(0.01)$ & $21(0.03)$ \\
Genotype H63D/N & $16(0.25)$ & $200(0.26)$ \\
Genotype N/N & $48(0.74)$ & $550(0.71)$ \\
OR & $0.9 ; 95 \% \mathrm{CI} 0.5-1.6$ \\
Allele H63D & $18(0.14)$ & $242(0.16)$ \\
Allele N & $112(0.86)$ & $1300(0.84)$ \\
\hline
\end{tabular}

*OR refers to the association of alleles with GDM risk.

observed that H63D mutation is associated with approximately 7 -fold increase in the risk of having class $\mathrm{B}$ GDM, which is treated by insulin (OR 7.4, 95\% CI 1.8 30.5).

The fact that H63D mutation in HFE gene can complicate the clinical manifestations of abnormal carbohydrate metabolism was showed by Mozsulski et al. It was for the first time indicated that being a H63D carrier is a risk factor for nephropathy in type 2 diabetic patients [20]. Also Mihailova et al. found the high prevalence of this mutation in type 2 diabetic subjects with proliferative retinopathy, neuropathy, strokes [21]. Qi et al. conducted a nested case-control study of 714 incident cases of type 2 diabetes. They detected significant effect of $\mathrm{H} 63 \mathrm{D}$ and $\mathrm{C} 282 \mathrm{Y}$ on the body iron stores and suggested the interaction between HFE genotypes and heme iron 
Table 5. C282Y and H63D mutations in case subjects with different classes GDM.

\begin{tabular}{lccc}
\hline & $\begin{array}{c}\text { Class A1, } \\
\text { (frequency) }\end{array}$ & $\begin{array}{c}\text { Class A2, } \\
\text { (frequency) }\end{array}$ & $\begin{array}{c}\text { Class B, } \\
\text { (frequency) }\end{array}$ \\
\hline All subjects & $40(0.615)$ & $14(0.215)$ & $11(0.17)$ \\
C282Y allele & $2(0.025)$ & $1(0.035)$ & $0(0.00)$ \\
$\begin{array}{l}\text { Variant carrier } \\
\text { C282Y/C282Y and } \\
\text { C282Y/N }\end{array}$ & $2(0.05)$ & $1(0.07)$ & $0(0.00)$ \\
H63D allele & $5(0.06)$ & $6(0.21)$ & $7(0.32)$ \\
$\begin{array}{l}\text { Variant carrier } \\
\text { H63D/H63D and }\end{array}$ & $5(0.11)$ & $5(0.36)$ & $7(0.64)$ \\
H63D/N & & & \\
\hline
\end{tabular}

intake in relation to the risk of type 2 diabetes [11].

The results of our study indicate that H63D and C282Y mutations do not provoke the gestational diabetes. But H63D genotype can enhance GDM manifestation, because the abnormal iron metabolism affects on the glucose and insulin homeostasis of the body. It means the use of insulin in diabetes therapy for correction carbohydrate metabolism in women with B1 and B2 classes in comparison with A1. It should be noted that two subjects with B2 GDM that participated in this study were H63D heterozygotes. Insulin in high doses was used for their treatment to achieve the adequate glucose level.

Abnormal iron metabolism may lead to excessive iron accumulation during the pregnancy, because there is no physiological blood loss in this period. Iron overload impedes the insulin extraction in the liver, so it causes the development of peripheral hyperinsulinemia [22]. Iron accumulation in $\beta$-cells of the pancreas significantly reduces insulin secretion [14]. Free radicals synthesized in reactions with iron injure cells [23,24]. Severe damage of renal, vessel, heart muscle tissues can speed up the complication development in people with diabetes, including the GDM.

We suppose that iron supplementation during pregnancy should be corrected depending on the H63D genotype in women with GDM. If H63D leads to aggravation of the GDM, it is quite probable that women with this mutation will suffer from sugar diabetes later in their life. The iron intake may prevent the normalization of carbohydrate metabolism in the body after GDM. Immediately after pregnancy, $5 \%-10 \%$ of patients with gestational diabetes are found to have diabetes, primarily type 2. Women with GDM have $40 \%-60 \%$ chance of developing diabetes in the next $5-10$ years [2]. Dorner et al. showed increased familial aggregation of diabetes on the maternal side of descendants with type 1 diabetes whose mothers had GDM [25]. Also Damm indicated that offspring after GDM pregnancies have an 8-fold risk of diabetes or prediabetes at the age of $19-27$ [26]. The possible link between HFE mutations and risk of diabetes mellitus manifestation after GDM requires thorough long-term researches.

In summary, we discovered the association between H63D genotype and the severity of GDM in Belarusian patients. Our data indicated that H63D mutation is associated with approximately 7 -fold increase in the risk of having class B GDM, which is treated by insulin.

\section{REFERENCES}

[1] American Diabetes Association, "Diagnosis and Classification of Diabetes Mellitus," Diabetes Care, Vol. 32, Suppl. 1, 2009, pp. S62-S67. doi:10.2337/dc09-S062

[2] American Diabetes Association, "Gestational of Diabetes Mellitus," Diabetes Care, Vol. 27, Suppl. 1, 2004, pp. S88-S90. doi:10.2337/diacare.27.2007.S88

[3] Z. V. Zabarouskaya, O. V. Muliarchik and T. A. Gdanova, "The Gestational Diabetes Mellitus Problems: The Main Aspects of the Pathogenesis, Clinical-Diagnostic Criteria, Principles of Treatments," Medicinskie Novosti, No. 12, 2002, pp. 12-19.

[4] M. Hod, "Textbook of Diabetes and Pregnancy," 1st Edition, Martin Dunitz, London \& New York, 2003.

[5] P. Moleda, A. Binczak-Kuleta, K. Homa, K. Safranow, Z. Celewicz, A. Syrenicz, A. Stefanski, A. Fronczyk and L. Majikowska, "The Common C49620T Polymorphism in the Sulfonylurea Receptor Gene SUR (ABCC8) in Patients with Gestational Diabetes and Subsequent Glucose Metabolism Abnormalities," Experimental Diabetes Researches, Published Online, 2012.

[6] A. Papadopoulou , K. F. Lynch, N. Shaat, R. Hakansson, S. A. Ivarsson, K. Berntorp, C. D. Agardh and A. Lernmark, "Gestational Diabetes Mellitus Is Associated with TCF7L2 Gene Polymorphisms Independent of HLA-DQB1*0602 Genotypes and Islet Cell Autoantibodies," Diabetic Medicine, Vol. 28, No. 9, 2011, pp. 1018-1027. doi:10.1111/j.1464-5491.2011.03359.x

[7] H. R. Frigeri, I. C. Santos, R. R. Rea, A. C. Almeida, C. M. Fadel-Picheth, F. O. Pedrosa, E. M. Souza, F. G. Rego and G. Picheth, "Low Prevalence of Glucokinase Gene Mutations in Gestational Diabetic Patients with Good Glycemic Control," Genetics and Molecular Researches, Vol. 11, No. 2, 2012, pp. 1433-1441. doi:10.4238/2012.May.18.2

[8] I. C. Santos, D. R. Daga, H. R. Frigeri, R. R. Rea, A. C. Almeida, E. M. Souza, F. O. Pedrosa, C. M. FadelPicheth and G. Picheth, "The Functional Polymorphisms $-429 \mathrm{~T}>\mathrm{C}$ and $-374 \mathrm{~T}>\mathrm{A}$ of the RAGE Gene Promoter Are not Associated with Gestational Diabetes in Euro-Brazilians," Genetics and Molecular Researches, Vol. 9, No. 2, 2010, pp. 1130-1135. doi:10.4238/vol9-2gmr817

[9] K. Klein, P. Haslinger, D. Bancher-Todesca, H. Leipold, M. Knöfler, A. Handisurya, A. Kautzky-Willer and C. Worda, "Transcription Factor 7-Like 2 Gene Polymorphisms and Gestational Diabetes Mellitus," Journal of Maternal-Fetal and Neonatal Medicine, Vol. 25, No. 9, 2012, pp. 1783-1786. doi:10.3109/14767058.2012.663831

[10] E. Causa, U. Hanusch-Enserer, M. Bischof, M. Spak, K. 
Kostner, A. Tammaa, A. Dunky and P. Ferenci, "Increased C282Y Heterosigosity in Gestational Diabetes," Fetal Diagnosis and Therapy, Vol. 5, No. 5, 2005, pp. 349-354. doi:10.1159/000086811

[11] L. Qi, J. Meigs, J. E. Manson, J. Ma, D. Hunter, N. Rifai and F. B. Hu, "HFE Genetic Variability, Body Iron Stores, and the Risk of Type 2 Diabetes in US Women," Diabetes, Vol. 54, No. 12, 2005, pp. 3567-3572. doi:10.2337/diabetes.54.12.3567

[12] D. J. Halsall, I. McFarlane, J. Luan, T. M. Cox and N. J. Wareham, "Typical Type 2 Diabetes Mellitus and HFE Gene Mutations: A Population-Based Case-Control Study," Human Molecular Genetics, Vol. 12, No. 12, 2003, pp. 13611365. doi:10.1093/hmg/ddg149

[13] J. N. Feder, A. Gnirke, W. Thomas, Z. Tsuchihashi, D. A. Ruddy, A. Basava, F. Dormishian, R. Domingo Jr., M. C. Ellis, A. Fullan, L. M. Hinton, N. L. Jones, B. E. Kimmel, G. S. Kronmal, P. Lauer, V. K. Lee, D. B. Loeb, F. A. Mapa, E. McClelland, N. C. Meyer, G. A. Mintier, N. Moeller, T. Moore, E. Morikang, C. E. Prass, L. Quintana, S. M. Starnes, R. C. Schatzman, K. J. Brunke, D. T. Drayna, N. J. Risch, B. R. Bacon and R. K. Wolff, “A Novel MHC Class I-Like Gene Is Mutated in Patients with Hereditary Hemochromatosis," Nature Genetics, Vol. 13, No. 4, 1996, pp. 399-408. doi:10.1038/ng0896-399

[14] J. M. Fernandes-Real, A. Lopes-Bermejo and W. Ricard, "Cross-Talk between Iron Metabolism and Diabetes," Diabetes, Vol. 51, No. 8, 2002, pp. 2348-2354.

[15] S. Swaminathan, V. A. Fonseca, M. G. Alam and S. V. Shah, "The Role of Iron in Diabetes and Its Complications," Diabetes Care, Vol. 30, No. 7, 2007, pp. 1926-1933. doi:10.2337/dc06-2625

[16] O. V. Muliarchik and Z. V. Zabarouskaya, "Diagnostic Features of Gestational Diabetes Mellitus and Treatment during Pregnancy," Belarusian Medical Journal, No. 2, 2002, pp. 41-42.

[17] L. N. Sivitskaya and A. I. Kushniarevich, "Hereditary Haemochromatosis: C282Y and H63D Mutations Frequencies of HFE Gene in Belarus Population," Proceedings of the National Academy of Sciences of Belarus, Vol. 6, No 1,
2007, pp. 414-418.

[18] C. C. Mathew, "The Isolation of High Molecular Weight Eucaryotic DNA," In: J. M. Walker, Ed., Methods in Molecular Biology, Human Press, Clifton, 1984, pp. 31-34.

[19] P. N. Babich, A. V. Chubenko and S. N. Lapach, "Application of Modern Statistical Methods in Clinical Trials. Part 3. Odds Ratio: Concept, Computation and Interpretation," Ukrainian Medical Journal, Vol. 46, No. 2, 2004, pp. 138-144.

[20] D. K. Moczulski, W. Grzeszczak and B. Gawlik, "Role of Hemochromatosis C282Y and H63D Mutations in HFE Gene in Development of Type 2 Diabetes and Diabetic Nephropathy," Diabetes Care, Vol. 24, No. 7, 2001, pp. 1187-1191.

[21] S. V. Mikhailova, O. V. Onopchenko, A. V. Sukhanov, V. N. Maksimov, T. K. Gaskina, A. G. Romaschenko and M. I. Voevoda, "Haplotypic Analysis for the HFE Gene in Russian Populations and in Patients with Common Deseases," Vestnik Vogis, Vol. 10. No. 3, 2006, pp. 504-513.

[22] E. Ferrannini, "Insulin Resistance, Iron and Liver," Lancet, Vol. 355, No. 9222, 2000, pp. 2181-2182. doi:10.1016/S0140-6736(00)02397-7

[23] L. W. Oberley, "Free Radicals and Diabetes," Free Radical Biology and Medicine, Vol. 5, No. 2, 1988, pp. 113112. doi:10.1016/0891-5849(88)90036-6

[24] T. T. Lao, P. L. Chan and K. F. Tam, "Gestational Diabetes Mellitus in the Last Trimester-A Feature of Maternal Iron Excess," Diabetic Medicine, Vol. 18, No. 3, 2001, pp. 218-223.

[25] G. Dorner, A. Plagemann and H. Reinagel, "Familial Diabetes Aggregation in Type I Diabetics: Gestational Diabetes an Apparent Risk Factor for Increased Diabetes Susceptibility in the Offspring," Experimental and Clinical Endocrinology and Diabetes, Vol. 89, No. 1, 1987, pp. 84-90. doi:10.1055/s-0029-1210631

[26] P. Damm, "Future Risk of Diabetes in Mother and Child after Gestational Diabetes Mellitus," International Journal of Gynecology and Obstetrics, Vol. 104, Suppl. 1, 2009, pp. S25-S26. 